\title{
A new species of Liolaemus related to $L$. nigroviridis from the Andean highlands of Central Chile (Iguania, Liolaemidae)
}

\author{
Jaime Troncoso-Palacios', Alvaro A. Elorza ${ }^{2,3}$, \\ German I. Puas ${ }^{2,3}$, Edmundo Alfaro-Pardo ${ }^{4}$
}

I Programa de Fisiologia y Biofisica, Instituto de Ciencias Biomedicas (ICBM), Facultad de Medicina, Universidad de Chile, Independencia 1027, Santiago, Chile 2 Centro de Investigaciones Biomedicas, Facultad de Ciencias Biologicas y Facultad de Medicina, Universidad Andres Bello, Republica 239, Santiago, Chile 3 Instituto Milenio de Inmunologia e Inmunoterapia, Portugal 49, Santiago, Chile 4 Gayana Ecolodge, Cadillal Km 7, Corral, Chile

Corresponding author: Jaime Troncoso-Palacios (jtroncosopalacios@gmail.com)

Academic editor: J. Penner | Received 10 April 2015 | Accepted 26 November 2015 | Published 20 January 2016

http://zoobank.org/E1446FEB-8061-42E7-9C95-2CD6E56E6E9C

Citation: Troncoso-Palacios J, Elorza AA, Puas GI, Alfaro-Pardo E (2016) A new species of Liolaemus related to L. nigroviridis from the Andean highlands of Central Chile (Iguania, Liolaemidae). ZooKeys 555: 91-114. doi: 10.3897/ zookeys. 555.6011

\begin{abstract}
The Liolaemus nigroviridis group is a clade of highland lizards endemic to Chile. These species are distributed from northern to central Chile, and currently there are no cases of sympatric distribution. This study describes a new species, Liolaemus uniformis sp. n., from this group, and provides a detailed morphological characterization and mitochondrial phylogeny using cytochrome-b. Liolaemus uniformis was found in sympatry with $L$. nigroviridis but noticeably differed in size, scalation, and markedly in the color pattern, without sexual dichromatism. This new species has probably been confused with L. monticola and L. bellii, both of which do not belong to the nigroviridis group. The taxonomic issues of this group that remain uncertain are also discussed.
\end{abstract}

\section{Keywords}

Liolaemus nigroviridis, L. uniformis sp n., lizard, Cyt-b, mtDNA

Copyright Jaime Troncoso-Palacios et al. This is an open access article distributed under the terms of the Creative Commons Attribution License (CC BY 4.0), which permits unrestricted use, distribution, and reproduction in any medium, provided the original author and source are credited. 


\section{Introduction}

The Liolaemus nigroviridis group is a clade of highland lizards endemic to central and northern Chile, the species of which are allopatrically distributed (Pincheira-Donoso and Núnez 2005). Almost all species of this group have a complicated taxonomic history with several cases of synonymies (e.g. Núñez and Jaksic 1992, Pincheira-Donoso and Núñez 2007, Troncoso-Palacios 2013). In his book on lizards from northwest, northeast, and eastern Argentina, Cei (1993) proposed the nigroviridis group and included within it L. constanzae Donoso-Barros, 1961. Lobo (2001) performed the first cladistic analysis of this group and, based on morphological characteristics, included the following species: L. campanae Hellmich, 1950, L. lorenzmuelleri Hellmich, 1950, L. maldonadae Núñez, Navarro \& Loyola, 1991, and L. nigroviridis Müller \& Hellmich, 1932. Later, Lobo (2005), updating the morphological phylogeny, added to the nigroviridis group L. nigroroseus Donoso-Barros, 1966 and L. isabelae Navarro \& Núñez, 1993, but excluded L. lorenzmuelleri.

Pincheira-Donoso and Núnez (2005), through phenetic analysis recovered all of the species listed by Lobo (2005) within the nigroviridis group and also reincorporated $L$. lorenzmuelleri and $L$. constanzae. Furthermore, $L$. constanzae was listed with two subspecies, L. c. constanzae and $L$. c. donosoi Ortiz, 1975. These authors also incorporated L. juanortizi Young-Downey \& Moreno, 1991 and L. melanopleurus (Philippi, 1860), the latter of which was included as incertae sedis. Moreover, L. nigroroseus was considered a junior synonym of $L$. constanzae, as has also been proposed by other authors (Núñez and Jaksic 1992, Troncoso-Palacios 2013), while L. campanae was regarded as a junior synonym of $L$. nigroviridis. In fact, $L$. campanae was previously described as a subspecies of $L$. nigroviridis (Hellmich 1950) and later proposed to be a synonym of L. nigroviridis (Núnez and Jaksic 1992, Valencia et al. 1979).

Lobo et al. (2010) accepted all of the species listed by Pincheira-Donoso and Núnez (2005) as members of the nigroviridis group, except for L. donosoi which they placed into the nigromaculatus group. Finally, Troncoso-Palacios (2013) indicated that $L$. donoso $i$ is a junior synonym of $L$. constanzae, as previously suggested (Núnez and Jaksic 1992, Veloso et al. 1982), and recognized the seven species listed by Lobo et al. (2010) as members of the nigroviridis group - L. constanzae, L. isabelae, L. juanortizi, L. lorenzmuelleri, L. maldonadae, L. melanopleurus, and L. nigroviridis.

Very few studies have used molecular data within this group. Schulte and MorenoRoark (2010) constructed a mitochondrial phylogeny of 733 Iguanian lizards. The authors concluded that $L$.n. nigroviridis, and $L$. n. campanae are sister taxa and that $L$. isabelae does not belong to the nigroviridis group. Cianferoni et al. (2013) performed a cytochrome-b (Cyt-b) phylogeographic study in L. nigroviridis populations and proposed that this species could contain at least two different species-level lineages.

In a field trip to the vicinity of Piuquenes (Valparaíso Region, Chile), we believe we found some populations probably previously assigned to Liolaemus monticola Müller \& Hellmich, 1932 by Núñez et al. (2010:57). Subsequent $C y t-b$ phylogenetic analysis 
and morphological comparisons determined that this population represents a new species that belongs to the nigroviridis group. This new species occurred in sympatry with $L$. nigroviridis, constituting the first case of sympatry within this group of lizards.

The current study describes this new species and provides a full diagnosis in regards to other species of the nigroviridis group. Although the color pattern of this new species resembles L. juanortizi and L. lorenzmuelleri, the scalation is markedly different and the distribution is allopatric ( $>240 \mathrm{~km}$ of separation). Moreover, various taxonomical aspects of the nigroviridis group that require attention are discussed.

\section{Materials and methods}

\section{Morphological data and analyses}

Specimens of all species currently considered within the nigroviridis group were examined. Morphological characteristics were examined according to Etheridge (1995) and Lobo (2005). Body measurements were taken with a digital Vernier caliper (0.02 $\mathrm{mm}$ precision) and given as the mean \pm standard deviation $(\mathrm{x} \pm \mathrm{SD})$. We applied a Kolmogorov-Smirnov test to verify data normality, a subsequent t-test or MannWhitney $U$ test was used if data passed or failed the normality test, respectively, to compare scale count (midbody, dorsal and ventral) and size (snout vent length, SVL) of the new species against some related species (Liolaemus constanzae, L. juanortizi, L. lorenzmuelleri and L. nigroviridis). Only significant results are presented. Scales were observed with different magnifying lenses. Scalation and measurements were recorded on the right side of the specimen. Dorsal scales were counted between the occiput and the anterior border of the hind limbs. Ventral scales were counted from the mental scale to the anterior margin of the cloacal opening. Stomach and intestinal contents were analyzed under a binocular stereoscope for one specimen of the new species. Data for the midbody scales of Liolaemus juanortizi were taken from one revised specimen and six reported in Young-Downey and Moreno (1991). Classification was carried out considering species currently assigned to the nigroviridis group (Troncoso-Palacios 2013). Liolaemus isabelae is included in the comparison but the relationship of this species with the nigroviridis group is uncertain (see Discussion). The examined specimens are listed in Appendix I. Some mapping data were taken from existing literature or field observations without specimen collection: 1) L. nigroviridis from Manque (Mella 2005), El Arpa and El Roble (Cianferoni et al. 2013), Riecillo (Núńez et al. 2010), Campana (Hellmich 1050), Chepical and Juncal (field observations, $32^{\circ} 16$ 'S $-70^{\circ} 30^{\prime} \mathrm{W}$ and $32^{\circ} 53^{\prime} \mathrm{S}-70^{\circ} 07^{\prime} \mathrm{W}$ respectively); 2) L. maldonadae from Los Molles (Núñez et al. 1991). Acronyms used are: Museo Nacional de Historia Natural de Chile (MNHNCL), Museo de Zoología de la Universidad de Concepción (MZUC) and Colección de Flora y Fauna, Profesor Patricio Sánchez Reyes of the Pontificia Universidad Católica de Chile (SSUC). 


\section{DNA purification, PCR amplification, and sequencing}

Samples from liver and thigh muscle were obtained from ethanol-fixed lizards which were subject to a rehydration process according to Coura (2005). Samples were washed twice in distilled water for $5 \mathrm{~min}$ at $55^{\circ} \mathrm{C}$ to remove the fixative and then rehydrated with $1 \mathrm{x}$ Tris/EDTA for $5 \mathrm{~min}$ at $55^{\circ} \mathrm{C}$ and then $1 \mathrm{M}$ Tris $\mathrm{pH} 7.5$, at $55^{\circ} \mathrm{C}$ overnight. Right after, samples were digested with proteinase $\mathrm{K}(20 \mathrm{mg} / \mathrm{ml})$ at $55^{\circ} \mathrm{C}$ overnight. Genomic DNA isolation (mitochondrial and nuclear) was done with the Wizard ${ }^{\bullet}$ Genomic DNA Purification kit (Cat \# A1120, Promega, USA) following manufacturer's instructions. The mitochondrial gene $C y t-b$ was amplified from total DNA through two phase conventional PCR with the primers GLUDGL (5'-TGA CTT GAA RAA CCA YCG TTG-3') and CB3 (5'-GGC AAA TAG GAA RTA TCA TTC-3'), reported in TorresPérez et al. (2009), to generate a 700bp amplicon. PCR reactions were performed with the SapphireAmp ${ }^{\circ}$ Fast PCR Master Mix (Cat \# RR350A, Takara Clontech, USA) using $100 \mathrm{ng}$ of total genomic DNA as a template and following the instruction manual. Two-phase PCR cycling was as follows: Phase 1 , initial $98^{\circ} \mathrm{C}$ denaturation for $3 \mathrm{~min}$, then 5 cycles of $98^{\circ} \mathrm{C}$ denaturation for $30 \mathrm{~s}, 47^{\circ} \mathrm{C}$ annealing for $45 \mathrm{~s}$ and $72^{\circ} \mathrm{C}$ extension for $45 \mathrm{~s}$. The Phase 2 , next 40 cycles of $98^{\circ} \mathrm{C}$ denaturation for $30 \mathrm{~s}, 58^{\circ} \mathrm{C}$ annealing for $45 \mathrm{~s}$ and $72{ }^{\circ} \mathrm{C}$ extension for $45 \mathrm{~s}$. A final $72{ }^{\circ} \mathrm{C}$ extension step for 5 min was added to finish the PCR. The $700 \mathrm{bp}$ PCR amplicon was checked by DNA electrophoresis on a $1 \%$ agarose gel in $1 \mathrm{x}$ Tris-Acetate-EDTA (TAE) buffer. The amplicons were purified with the E.Z.N.A. ${ }^{\circledR}$ Cycle-Pure Kit (Cat \# D6492-02, Omega Biotek, USA) and sent for capillary sequencing to Macrogen, Korea.

\section{Phylogenetic reconstruction}

The accession numbers of the $C y t-b$ mitochondrial loci sequences generated in this study and the sequences obtained from GenBank are indicated in Appendix II. Forty three nucleotide sequences involved in the analysis were aligned using MUSCLE (Edgar 2004). We used the JModelTest v2.1.7 (Darriba et al. 2012, Guidon and Gascuel $2003)$ to select an appropriate substitution model $(\mathrm{HKY}+\mathrm{G}+\mathrm{I})$, with a BIC index. We performed a Bayesian inference (BI) analyses with MrBayes v3.1.5 (Ronquist and Huelsenbeck 2003). Two independent analyses, each consisting of two groups of four chains that run independently, that were run for $15.0 \times 10^{6}$ generation and a at sample frequency $=1000$. Priors were let by default. Phymaturus vociferator Pincheira-Donoso 2004, was selected as the outgroup. The $25 \%$ of samples were discarded as burnin when calculating the convergence diagnostic, assessed examining values of average standard deviation of the Potential Scale Reduction Factor (PSRF) for all parameters. 


\section{Results}

The genetic tree constructed from mitochondrial DNA (mtDNA) (Fig. 1) placed the newly identified Liolaemus species as a sister taxon of L. nigroviridis (posterior probability pp =1). However, no data are available for most of the species in the nigroviridis group as sample collection is hampered by the high altitudes where these species inhabit. Therefore, the discovered topology should be considered preliminary (see Discussion). Liolaemus monticola is nested with strong support ( $\mathrm{pp}=1$ ) in the monticola group, the sister clade of the nigroviridis group. Liolaemus bellii is not closely related to the new Liolaemus or L. monticola, and is nested in a node with polytomy.

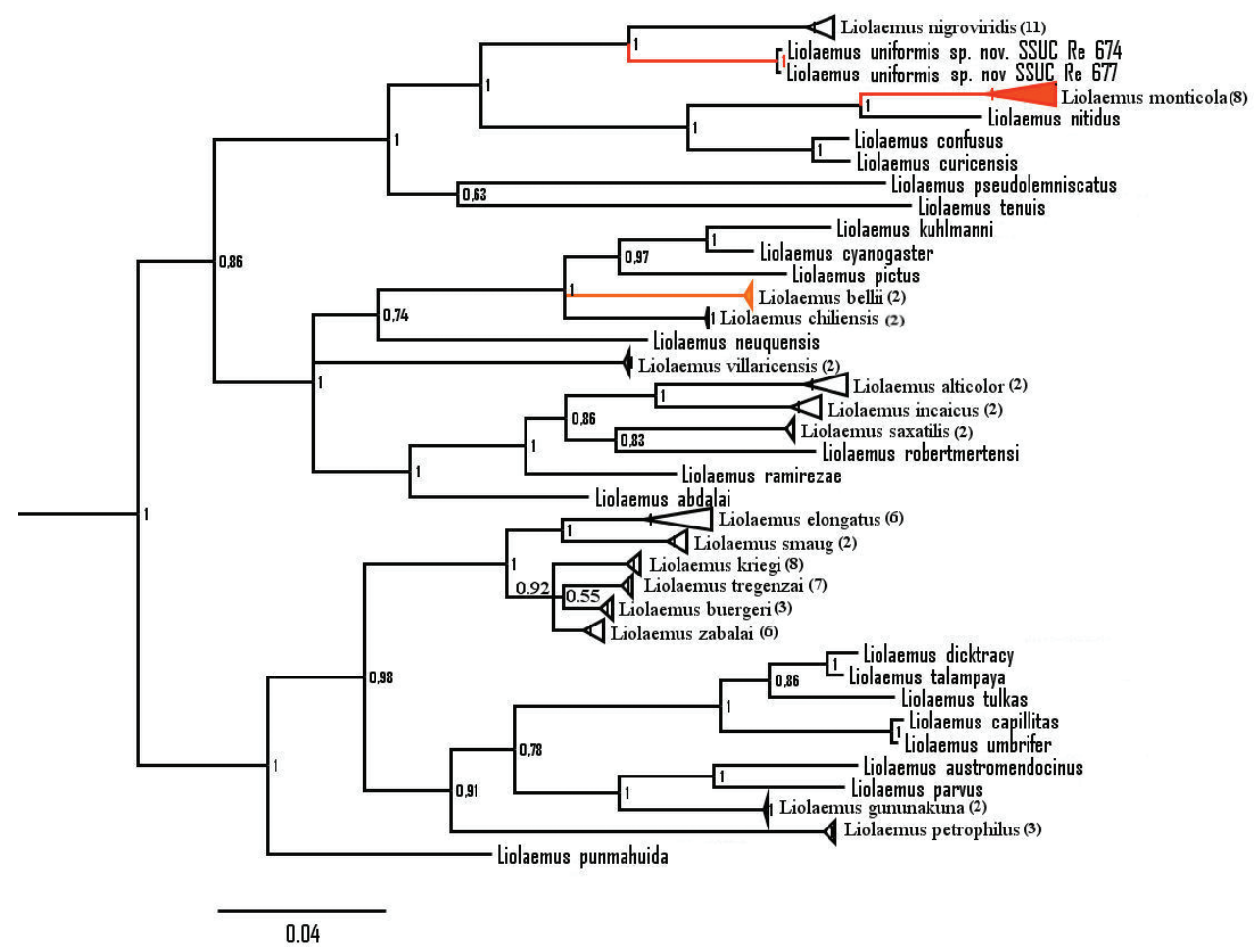

Figure I. Bayesian inference of phylogeny tree using $C y t-b$ showing phylogenetic relationships of Liolaemus uniformis sp. n. (red) and related species (HKY+G+I model). Liolaemus bellii and L. monticola, probably confused with the new species, are also in red. Posterior probability is indicated at each node. Scale shows the number of substitutions per site. Number between parentheses indicates the number of sequences for the collapsed nodes. 


\section{Liolaemus uniformis sp. $\mathrm{n}$.}

http://zoobank.org/B412BEF2-C337-4472-A4CE-9AFD73876B07

Fig. 2A, B

Liolaemus altissimus altissimus (in part?), Mella. 2005, Guía Camp. Rep. Chil. Zon. Cent., p. 38.

Liolaemus monticola?, Núñez et al. 2010, Bol. Mus. Nac. Hist. Nat., p. 57.

Holotype. SSUC Re 674. Adult male. Collected in the west shore of the Chepical Lagoon $\left(32^{\circ} 15^{\prime} \mathrm{S}-70^{\circ} 30^{\prime} \mathrm{W}\right)$, approximately $30 \mathrm{~km}$ NE Alicahue, San Felipe de Aconcagua Province, Valparaíso Region, Chile. Collectors: J. Troncoso-Palacios and E. Alfaro. December, 2012.

Paratypes (Fig. 2C, D, E, F). SSUC Re 675, male. SSUC Re 676-78, three females. SSUC Re 679, juvenile. The same data as the holotype.

Etymology. The species name "uniformis" (Latin) refers to the lack of dorsal pattern and uniform color found for both males and females.

Diagnosis. Liolaemus uniformis is larger than L. constanzae (Mann-Whitney $\mathrm{U}=$ $0.5, \mathrm{P}<0.01$, Table 1). Liolaemus constanzae has sexual dichromatism, a feature absent in $L$. uniformis. Males of $L$. constanzae have a black vertebral line and black spots on the paravertebral fields (Fig. 3A), whereas L. uniformis has no dorsal pattern. Additionally, the southern distributional limit of $L$. constanzae in Agua Verde, Antofagasta Region, Chile (Ortiz 1975), is more than $750 \mathrm{~km}$ north of the type locality recorded for L. uniformis.

Liolaemus uniformis differs from L. isabelae (Fig. 3C), because in the latter the nasal and the rostral scales are in contact only in $25 \%$ of specimens, whereas in L. uniformis, these scales are always in contact. Males of $L$. isabelae have black ventral coloration, a yellow dorsal color with a black vertebral line, black bars in the paravertebral fields, and a black lateral band, or some males have a completely black dorsal color; all traits that are absent in L. uniformis. Additionally, the southern distributional limit of $L$. isabelae in Salar de Pedernales, Atacama Region, Chile (Pincheira-Donoso and Núñez 2005 ) is more than $650 \mathrm{~km}$ north of the type locality recorded for L. uniformis.

Liolaemus uniformis resembles L. lorenzmuelleri (Fig. 3E) and L. juanortizi (Fig. 3D), species suggested as conspecific (Pincheira-Donoso and Núñez 2005). However, the dorsal scales in L. lorenzmuelleri and L. juanortizi are noticeably larger than those of L. uniformis, and have a distinct "ovoid" shape. Liolaemus uniformis has more dorsal scales $(60.0 \pm 2.9)$ than L. lorenzmuelleri $(48.4 \pm 4.2)(\mathrm{t}=-5.4, \mathrm{P}<0.01)$. On the other hand, while only one specimen of $L$. juanortizi was examined, this one has 52 dorsal scales, which is below of the range for $L$. uniformis (Table 1). Liolaemus uniformis has more midbody scales $(60.4 \pm 1.7)$ than $L$. lorenzmuelleri $(54.9 \pm 4.5)(\mathrm{t}=2.6, \mathrm{P}<0.05)$ and L. juanortizi $(56.7 \pm 2.1)(\mathrm{t}=3.2, \mathrm{P}<0.05)$. Liolaemus lorenzmuelleri has a dark vertebral line and dark transversal lines running from the paravertebral fields to the flanks, whereas $L$. uniformis has no dorsal pattern. The dorsal pattern of $L$. juanortizi is very similar to $L$. lorenzmuelleri, but some specimens have a black ventral coloration, a black lateral band, and the lack of a dark vertebral line, whereas L. uniformis has no 


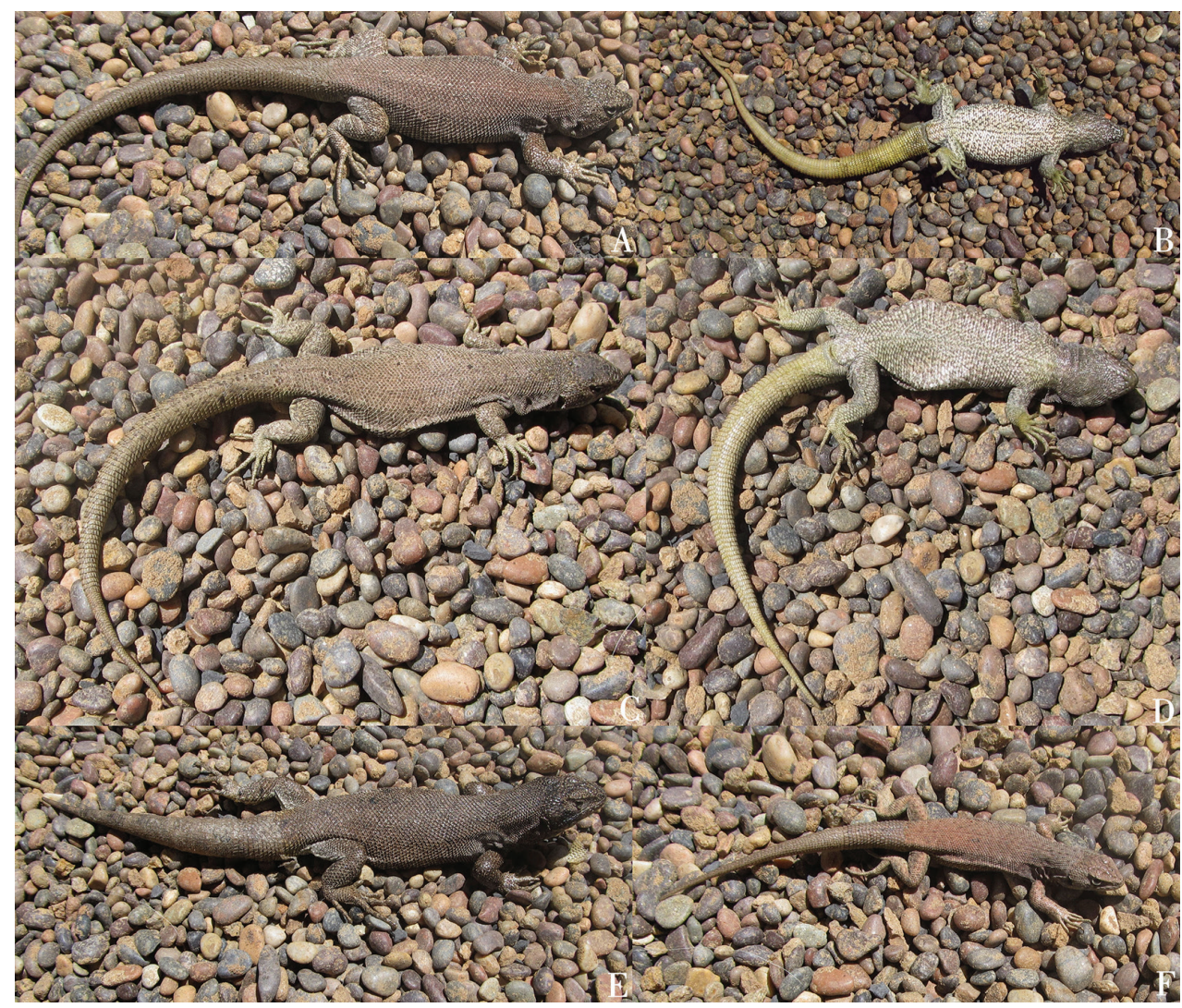

Figure 2. Liolaemus uniformis sp. n. A, B Holotype, male C, D Paratype, female E Paratype, male F Paratype, juvenile (unknown sex). All from the type locality.

black ventral color or black lateral band. Additionally, the southern distributional limit of L. lorenzmuelleri (Embalse La Laguna, Coquimbo Region, Chile) is more than 240 $\mathrm{km}$ north of the type locality recorded for L. uniformis; and the southern distributional limit of L. juanortizi in Quebrada Contrabando, Atacama Region, Chile (MNHNCL collection catalog, unpublished) is more than $520 \mathrm{~km}$ north of the type locality recorded for L. uniformis.

Liolaemus uniformis differs from L. melanopleurus (a species with only three known specimens from an undetermined location, Fig. 3B) in that the latter has a blue-gray dorsal coloration (Philippi 1860) and a black lateral band running from the axilla to the midbody, features absent in L. uniformis. Although the type locality of $L$. melanopleurus is undetermined, the syntypes were collected by Philippi in his journey through the Atacama Desert, between the vicinities of Copiapó $\left(27^{\circ} 23^{\prime} \mathrm{S}\right)$ and San Pedro de Atacama $\left(22^{\circ} 54^{\prime} \mathrm{S}\right)$, more than $530 \mathrm{~km}$ north of the type locality recorded for L. uniformis.

Liolaemus uniformis differs from L. maldonadae (Fig. 3F), because males of the latter have a yellowish or reddish dorsal color with black transverse dorsal and ventral bars and black lateral band, whereas L. uniformis has no dorsal pattern or black trans- 


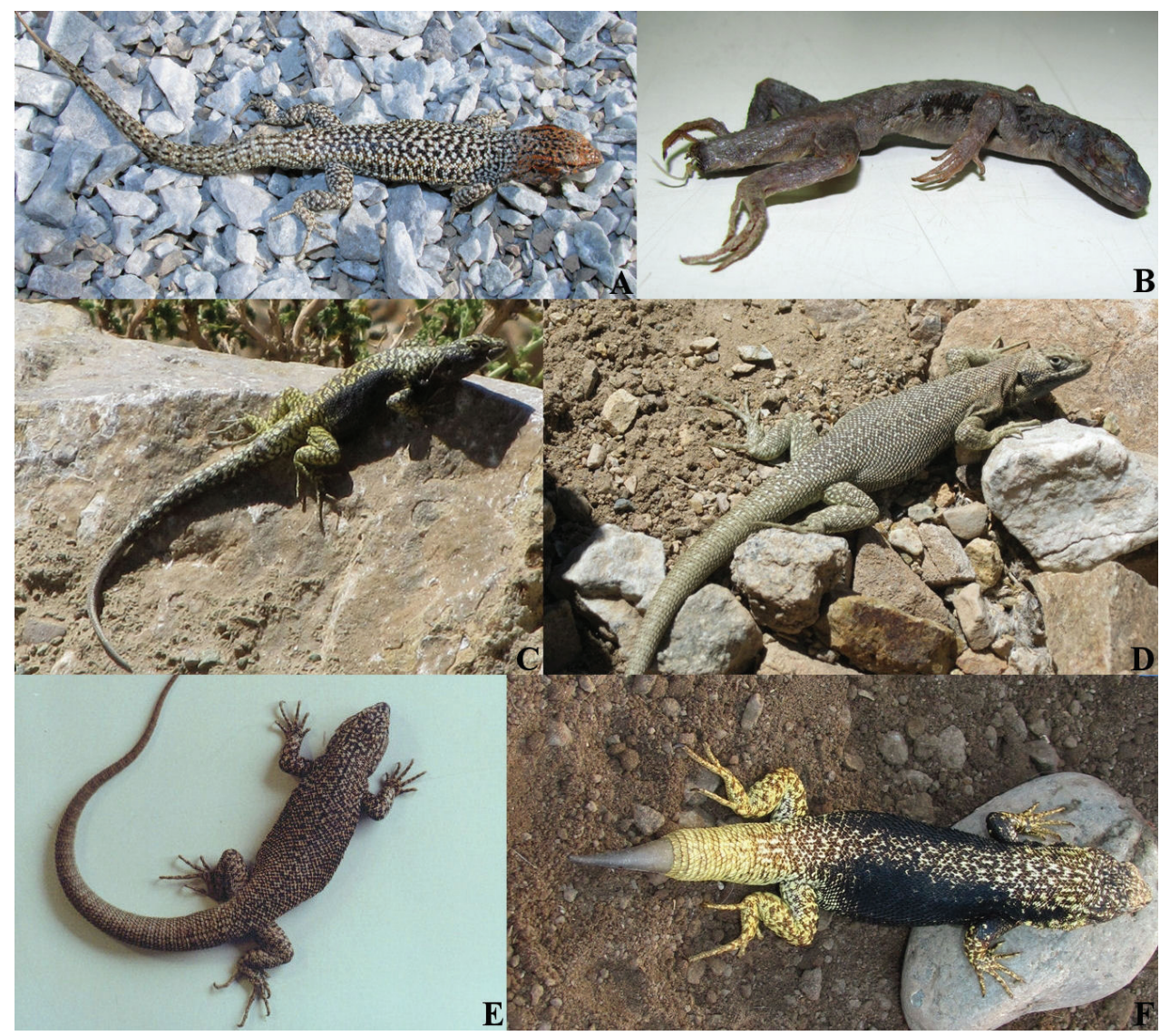

Figure 3. Chilean species of the nigroviridis group (with the exception of Liolaemus nigroviridis), ordered from north to south. A Liolaemus constanzae, male from vicinity of San Pedro (picture by JTP) B $L$. melanopleurus, male from Atacama (picture by JTP) C L. isabelae, male from Montandón (picture by JTP) D $L$. juanortizi, unknown sex specimen from road to Negro Francisco (picture by F. de Grotee) E $L$. lorenzmuelleri, unknown sex specimen from Embalse La Laguna (picture by A. Labra) F L. maldonadae, male from vicinity of Alcohuaz (picture by JTP).

verse ventral bars. Dorsal scales in $L$. maldonadae are noticeably larger than found in $L$. uniformis, and they have an "ovoid" shape. Dorsal and ventral scale counts in L. maldonadae do not overlap with the same scale counts in L. uniformis (Table 1). Finally, the southern distributional limit of L. maldonadae in Los Molles (Núñez et al. 1991) is more than $150 \mathrm{~km}$ north of the type locality of L. uniformis.

Liolaemus uniformis is found in sympatry with L. nigroviridis (Fig. 4), but is larger than L. nigroviridis (Mann-Whitney $\mathrm{U}=8.0, \mathrm{P}<0.05$, Table 1). Liolaemus uniformis also has more dorsal scales $(60.0 \pm 2.9)$ than $L$. nigroviridis $(49.4 \pm 2.7)(\mathrm{t}=7.4, \mathrm{P}<$ 0.01 ). Liolaemus nigroviridis has strongly mucronated dorsal scales, whereas $L$. uniformis has no mucrons (Fig. 5). Liolaemus nigroviridis has sexual dichromatism, absent in L. uniformis. Males of L. nigroviridis have a bluish or yellowish green dorsal color 
A new species of Liolaemus related to L. nigroviridis from the Andean highlands...

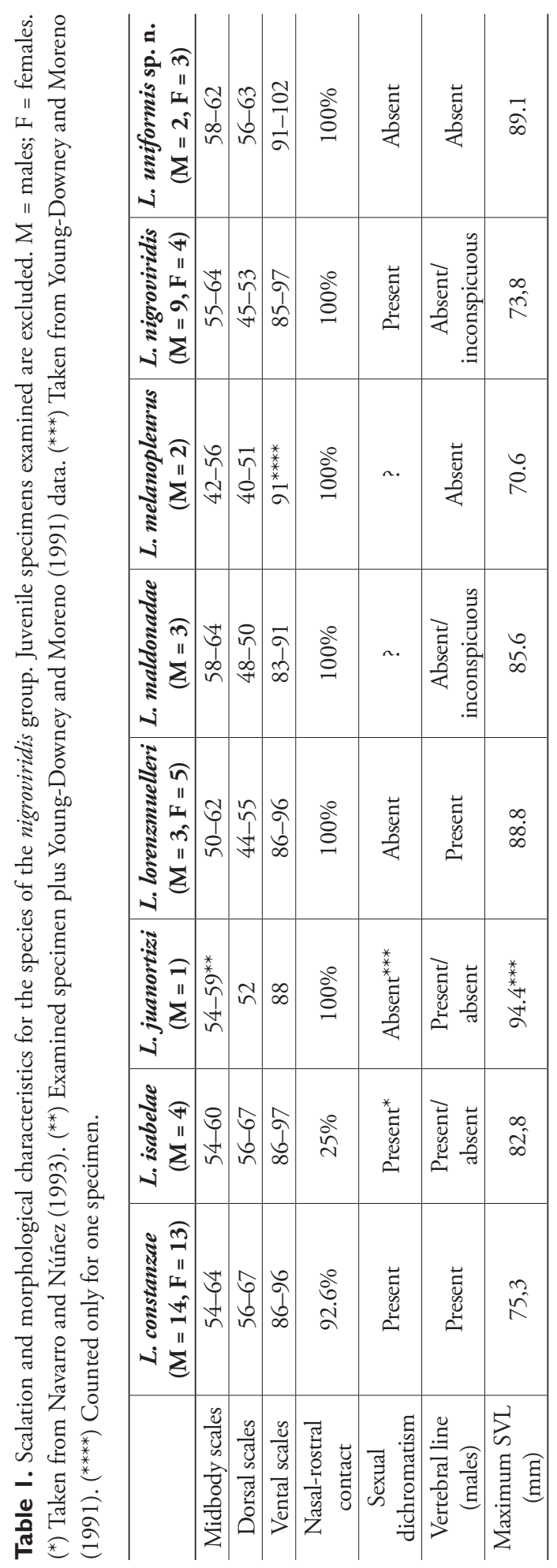




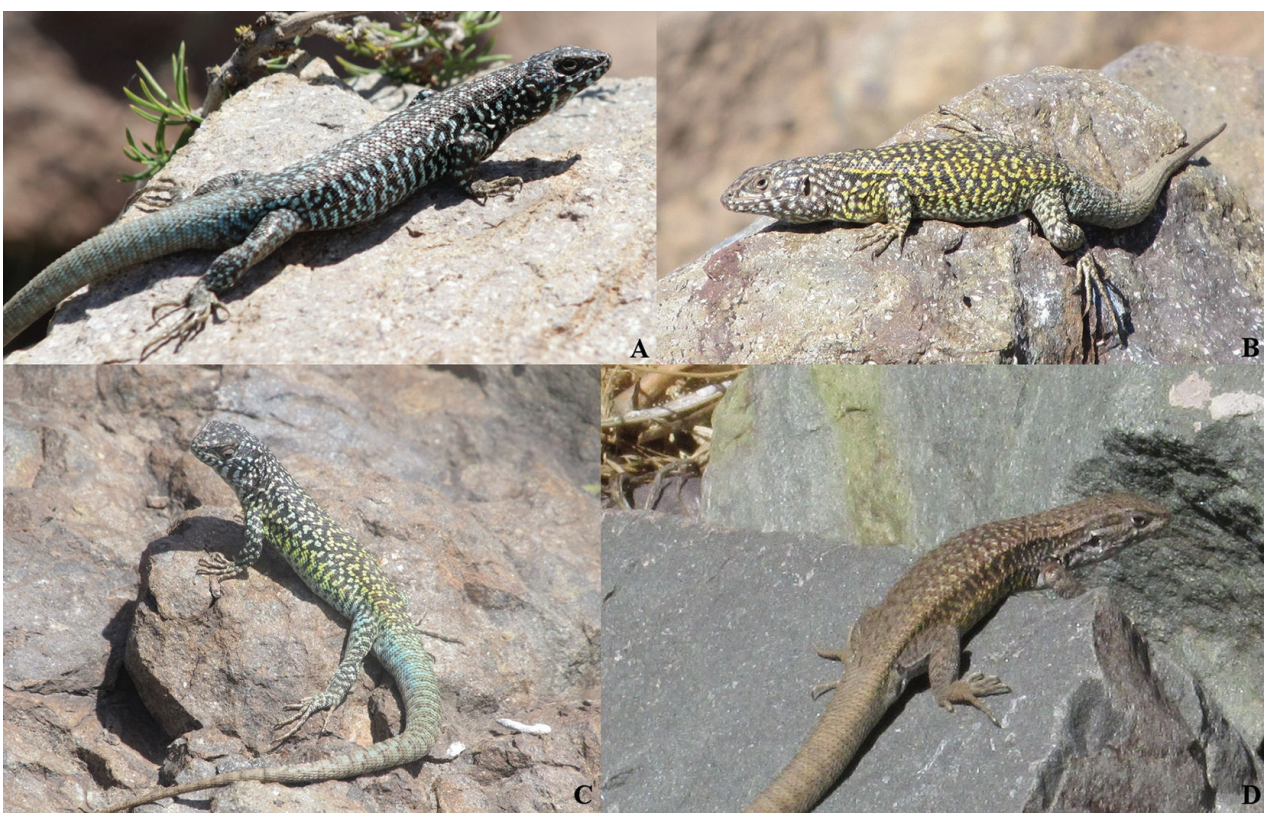

Figure 4. Variation in Liolaemus nigroviridis. A Male from Farellones (picture by H. Díaz) B Male from Carpa Mountain (picture by JTP) C Male from Provincia Mountain (picture by JTP) D Female from Juncal (picture by JTP).

with black reticulation, and females have a brown dorsal color with a black lateral band, black vertebral line, and black paravertebral spots. In contrast, L. uniformis has a brown dorsal color without any pattern.

Molecular data show that Liolaemus uniformis is not closely related to L. monticola (Fig. 1). Moreover, L. monticola is smaller (maximum SVL $=65.6 \mathrm{~mm}$ ) than $L$. uniformis (max. SVL $=89.1 \mathrm{~mm})(\mathrm{t}=3.9, \mathrm{P}<0.01)$ according to our samples, and although Pincheira-Donoso and Núnez (2005) recorded a max. SVL $=67.3 \mathrm{~mm}$ for L. monticola, the difference between both species is marked. Moreover, L. monticola exhibit a characteristic black lateral band between the axilla and midbody (diffuse in females), and males have white dots dispersed on the dorsum and a series of small black spots on the dorsum (Fig. 6). All these traits are absent in L. uniformis. The upper altitudinal limit of Liolaemus monticola distributions is $2000 \mathrm{~m}$ a.s.l. (Espinoza et al. 2004, Fuentes and Ipinza 1979), whereas L. uniformis has a lower altitudinal distribution limit of $2820 \mathrm{~m}$ a.s.l.

Molecular data show that Liolaemus uniformis is not closely related to L. bellii (Fig. 1). Moreover, L. bellii is smaller (maximum SVL $=80.8 \mathrm{~mm}$ ) than L. uniformis (max. $\mathrm{SVL}=89.1 \mathrm{~mm})(\mathrm{t}=2.7, \mathrm{P}<0.05)$. Liolaemus uniformis has more midbody scales $(60.4 \pm 1.7)$ than $L$. bellii $(52.9 \pm 2.6)(\mathrm{t}=6.1, \mathrm{P}<0.01)$; more dorsal scales $(60.0$ $\pm 2.9)$ than L. bellii $(43.3 \pm 3.1)(\mathrm{t}=10.2, \mathrm{P}<0.01)$; and more ventral scales $(96.2 \pm 4.8)$ than L. bellii (89.7 \pm 4.6$)$ (Mann-Whitney $\mathrm{U}=10.5, \mathrm{P}<0.05)$. Dorsal scales in L. bellii are strongly keeled and mucronated, whereas there are no mucrons in L. uniformis. 


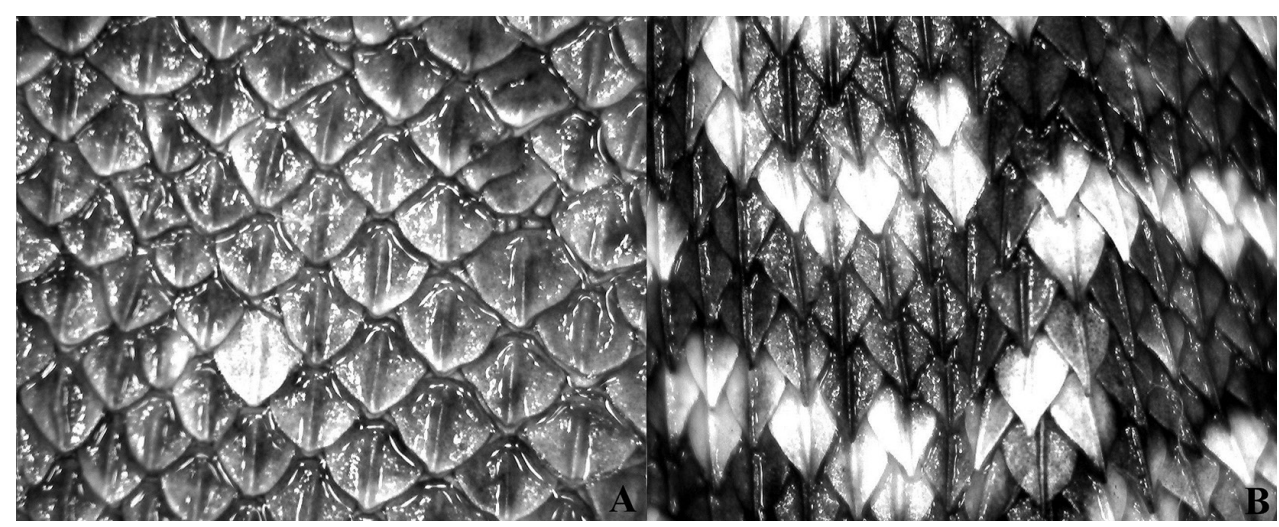

Figure 5. Dorsal scales, $8 \mathrm{~mm}$ width of view. A Male of Liolaemus uniformis sp. $\mathrm{n}$. B Liolaemus nigroviridis.

Moreover, L. bellii exhibit a characteristic series of black dorsal "W" o "V" shaped spots (Fig. 6), whereas L. uniformis has no dorsal pattern.

Description of the holotype. Adult male. SVL $=84.7 \mathrm{~mm}$. Horizontal diameter of the eye: $4.3 \mathrm{~mm}$. Subocular length: $4.5 \mathrm{~mm}$. Length of the fourth supralabial: 4.1 $\mathrm{mm}$. Head length (from the posterior border of the auditory meatus to the tip of the snout): $22.1 \mathrm{~mm}$. Head height (distance between the two ear openings): $10.4 \mathrm{~mm}$. Head width (at the level of ear openings): $15.8 \mathrm{~mm}$. Neck width: $12.4 \mathrm{~mm}$. Interorbital distance: $6.3 \mathrm{~mm}$. Ear-eye distance: $7.5 \mathrm{~mm}$. Internarine distance: $3.8 \mathrm{~mm}$. Ear width: $2.5 \mathrm{~mm}$. Ear height: $3.5 \mathrm{~mm}$. Axillary-groin distance: $34.9 \mathrm{~mm}$. Body width: $24.7 \mathrm{~mm}$. Forelimb length: $25.7 \mathrm{~mm}$. Hindlimb length: $46.1 \mathrm{~mm}$. Length of the right hand: $10.4 \mathrm{~mm}$. Length of the right foot: $22.4 \mathrm{~mm}$. Tail length (not autotomized): $132.4 \mathrm{~mm}$, with relation tail length $/ \mathrm{SVL}=1.56$. Pentagonal rostral scale, wider $(4.2$ $\mathrm{mm})$ than high $(1.4 \mathrm{~mm})$.

Two postrostrals. Four internasals. Heptagonal interparietal, with a central, small, and whitish central spot marking the position of the parietal eye. Interparietal smaller than the parietals, surrounded by seven scales. Seven scales between the interparietal and rostral. Thirteen scales between the occiput and the rostral. Orbital semicircle incomplete on the right side and complete on the left (formed by thirteen scales). Three supraoculars on the left side and four on the right. Six superciliary scales. Frontal area divided into three scales ( 1 posterior and 2 anterior). Preocular separated from the lorilabials by one loreal scale. Two scales between nasal and canthal. Nasal in contact with the rostral, surrounded by six scales. One row of lorilabials between the supralabials and subocular. Four lorilabials in contact with the subocular. Six supralabials, the fourth is curved upward without contacting the subocular. Four infralabials scales. Pentagonal mental scale, in contact with four scales. Four pairs of post-mental shields, the second is separated by two scales. Temporal scales smooth or slightly keeled, imbricated. Six temporal scales between the level of superciliary scales and the rictal level. Four scales on the anterior edge of the ear, which do not cover the auditory meatus. Poorly differ- 


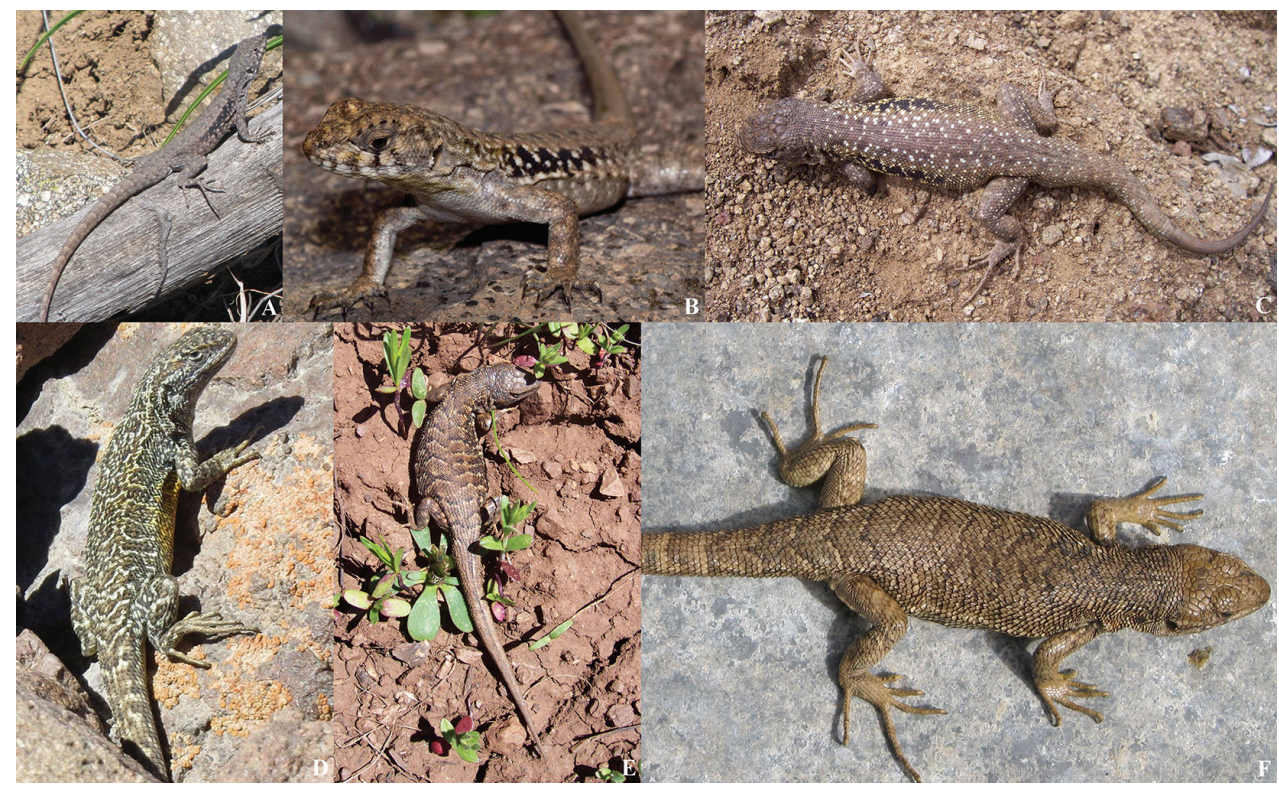

Figure 6. Variation in species probably confused with Liolaemus uniformis sp. n. A L. monticola from Salto de Apoquindo (picture by JTP) B L. monticola from La Cruz Mountain (picture by J. Abarca-Díaz) C $L$. monticola from Provincia Mountain (picture by JTP) D L. bellii from La Parva (JR Martini) E $L$. bellii from Lagunillas (picture by JTP) F L. bellii from San Ramón Mountain (picture by JTP).

entiated auricular scale, pentagonal and located at the upper part of the meatus. Thirty gulars between the auditory meatus. Lateral neck fold is "Y" shaped. Ventrolateral fold running from the neck to the groin. Dorsolateral fold slightly developed, running from the ear to the base of the tail. Midbody scales: 60. Dorsal scales are lanceolated, imbricated, keeled (without mucrons), with few interstitial granules. Dorsal smaller than the ventrals. Dorsal scales: 58. Ventrals scales are polymorphic (rounded, rhomboidal, pentagonal or hexagonal) smooth, imbricated, without interstitial granules. Ventrals: 91. Three precloacal pores. Supra-femoral scales lanceolate, imbricated, smooth or keeled. Infra-femoral scales lanceolate or rounded, smooth and imbricated. Supra-antebrachials scales are rounded or lanceolated, imbricated and smooth or keeled. Infra-antebrachials are rounded, imbricated and smooth. Dorsal scales of tail are pentagonal or rhomboidal, imbricated and keeled. Ventral tail scales are rounded or rhomboidal, smooth and imbricated. Lamellae of the fingers: I: 9, II: 13, III: 20, IV: 20 and V: 13. Lamellae of the toes: I: 11, II: 15, III: 21, VI: 27 and V: 17.

Color of the holotype in life. The specimen is notable for its lack of pattern and uniform color. The head is brown and darker than the body. There are several white dots dispersed over the head and cheeks. The dorsum is coppery brown and has a few white-spotted scales that did not form a pattern. The subocular is brown and crossed by three white, vertical lines. The dorsal surface of the tail is light brown and without a pattern. The limbs are a dorsal-brown, similar to the dorsal surface, with white dots 


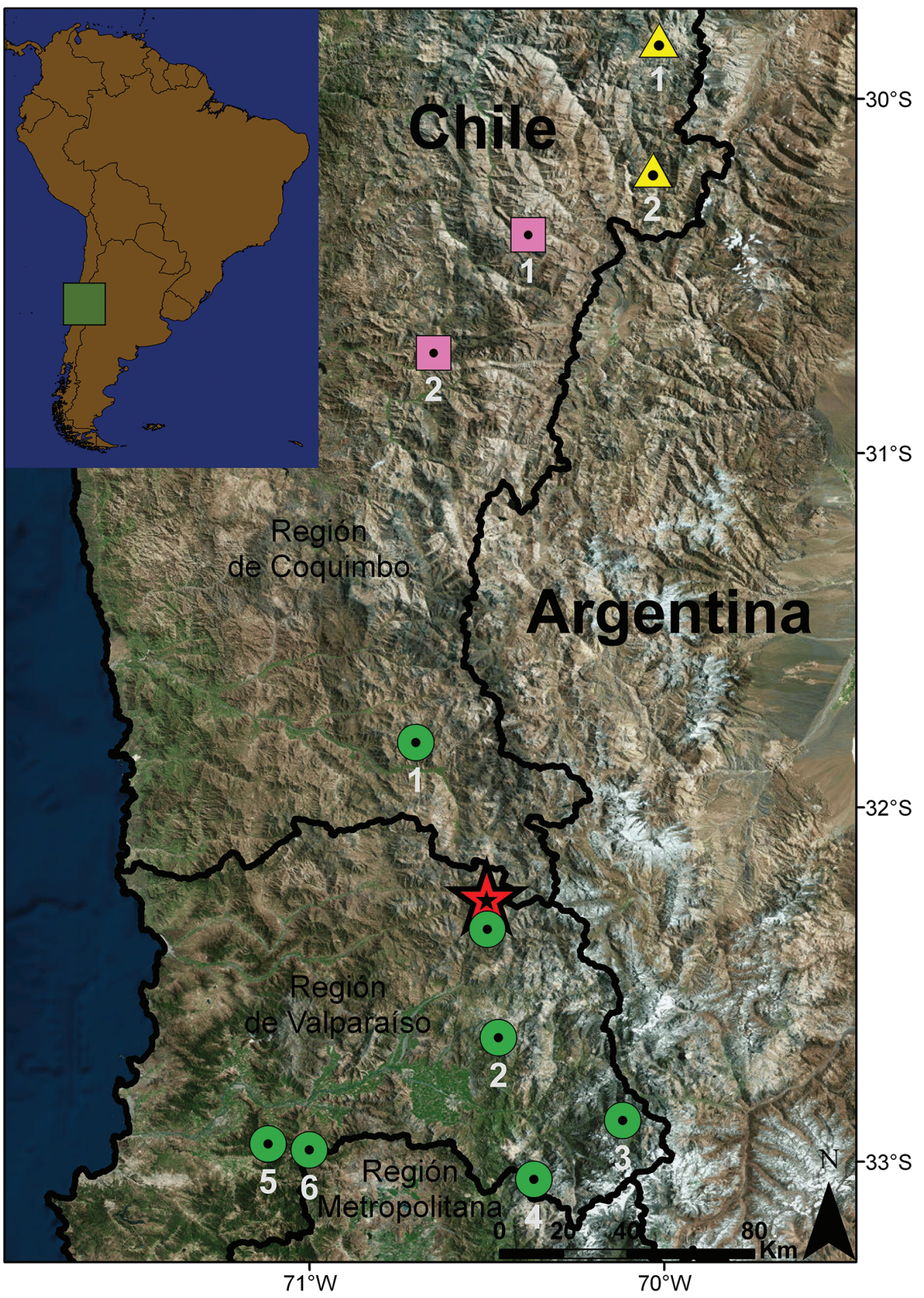

Figure 7. Distributional map for Liolaemus uniformis sp. n. along with geographically proximate species of the nigroviridis group. Red star: L. uniformis sp. n., Chepical Lagoon, type locality. Green circles: $L$. nigroviridis ( 1 = Manque, 2 = El Arpa, 3 = Juncal, $4=$ Riecillo, $5=$ La Campana, $6=$ El Roble, without number $=$ near Chepical Lagoon). Pink squares: $L$. maldonadae $(1=$ near Alcohuaz, $2=$ Los Molles). Yellow triangles: L. lorenzmuelleri $(1$ = Baños del Toro, 2 = Embalse La Laguna). 
dispersed on the forelimbs and white transversal lines on the hindlimbs. The flanks are whitish with abundant dark brown scales. Ventrally, the hands, feet, thighs, vent, and tail are yellowish. The belly is whitish with dark dispersed spots and a dark ventral stripe. The throat is whitish with a dark thick reticulation. The precloacal pores are orange.

Variation in the type series. Males are larger and more corpulent than females. In two males: SVL: 84.7-89.1 mm. Axilla-groin distance: $34.9-37.8 \mathrm{~mm}$. Head length: 21.9-22.1 mm. Head width: $15.8-16.3 \mathrm{~mm}$. Head height: $10.4-11.2 \mathrm{~mm}$. Leg length: 45.4-46.1 mm. Arm length: $25.0-25.8 \mathrm{~mm}$. Tail length: $132.4 \mathrm{~mm}$ in one specimen, with relation tail length/SVL $=1.56$ (autotomized in the other). In three females: SVL: 67.7-73.1 mm. Axilla-groin distance: 33.1-35.7 mm. Head length: 17.8-20.0 mm. Head width: $11.8-13.3 \mathrm{~mm}$. Head height: $7.5-8.3 \mathrm{~mm}$. Leg length: $32.0-34.8 \mathrm{~mm}$. Arm length: $19.2-21.3 \mathrm{~mm}$. Tail length: $98.1 \mathrm{~mm}$ in one specimen, with relation tail length $/ \mathrm{SVL}=1.45$ (autotomized in other).

The variation of the scalation in Liolaemus uniformis is as follows. Midbody scales: 58-62 $(60.4 \pm 1.7)$. Dorsal scales: 56-63 $(60.0 \pm 2.9)$. Ventral scales 91-102 (96.2 $\pm 4.8)$. Fourth finger lamellae: $17-20(19.0 \pm 1.4)$. Fourth toe lamellae: $25-27(26.4$ $\pm 0.9)$. Supralabial scales: 6 . Infralabial scales: $4-5$ ( $4.4 \pm 0.6)$. Interparietal scale pentagonal, hexagonal or heptagonal, bordered by $5-7$ scales $(6.0 \pm 0.7)$. Nasal and rostral always in contact. Precloacal pores in males: 3 . Precloacal pores are absent in females.

In general, all specimens have the pattern and color described for the holotype, with slight variations in shade. The male paratype has a dark brown throat. Two females have inconspicuous dark rings and an inconspicuous vertebral stripe on the dorsal surface of the tail. Also, two females have an olive hue on the snout. One female has a very inconspicuous series of dark crossbars on the paravertebral fields, which, while difficult to count, approximated eight. The juvenile has a similar pattern and color as the holotype, but it has an inconspicuous and fragmented dark vertebral line and inconspicuous dark spots on the paravertebral fields.

Distribution and natural history. This species is currently only known from the type locality in the surroundings of the Chepical Lagoon, approximately $30 \mathrm{~km} \mathrm{NE}$ of Alicahue, in the San Felipe de Aconcagua Province, Valparaíso Region, Chile (Fig. 7). Specimens were collected on the west shore of the Chepical Lagoon $\left(32^{\circ} 15^{\prime} \mathrm{S}-\right.$ $70^{\circ} 30^{\prime} \mathrm{W}, 3050 \mathrm{~m}$ a.s.l.). This new species was found inhabiting rocky areas with litthe shrubby vegetation composed mainly of high-Andean forbs, such as Chuquiraga oppositifolia and Azorella sp. (Fig. 8). This lizard was found in abundance and was observed to have saxicolous habits. It was active between 9:00 $\mathrm{h}$ and 18:00 $\mathrm{h}$ and took refuge under rocks. Moreover, this species was found in syntopy with Phymaturus alicahuense Núnez, Veloso, Espejo, Veloso, Cortés \& Araya 2010. Specimens were also observed at lower altitudes $\left(32^{\circ} 16^{\prime} \mathrm{S}-70^{\circ} 30^{\prime} \mathrm{W}, 2820 \mathrm{~m}\right.$ a.s.l.) in similar environments, altitudes at which this species was found in sympatry with a few specimens of L. nigroviridis.

One of the collected specimens had a yellow flower inside of its mouth. An analysis of intestinal contents showed that L. uniformis is omnivorous; plant and Hymenoptera remains were found. A large quantity of nematodes from an unidentified species was 


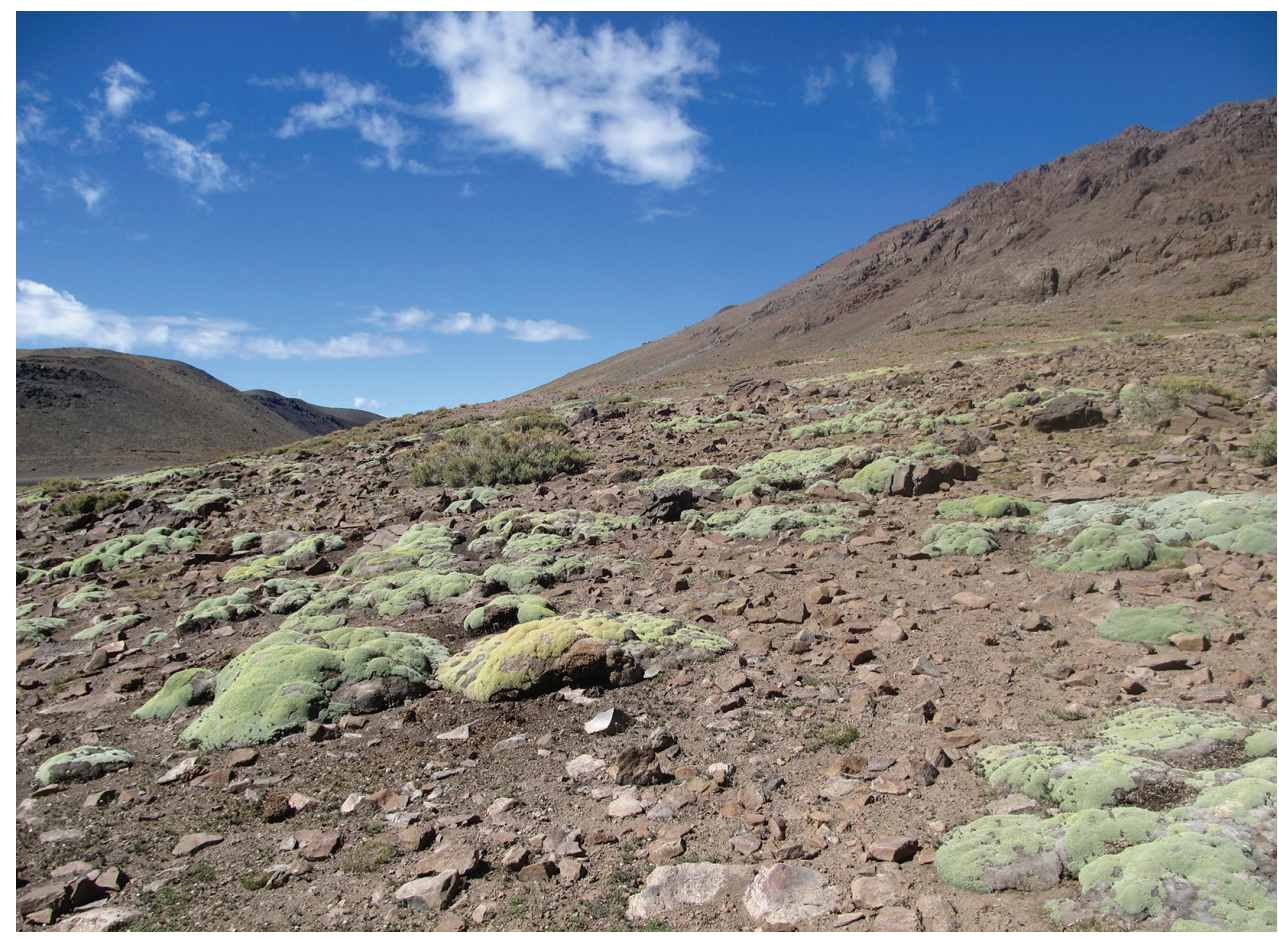

Figure 8. View of the type locality of Liolaemus uniformis sp. n., a high Andean environment.

found in the intestines. While the reproductive mode is yet unknown, at the time of sampling (December) no evidence of embryos was found but one female had several small oocytes. Comparisons with the reproductive modes of other species in the $n i$ groviridis group would not be helpful as there is little available data. It is known that L. nigroviridis is viviparous (Donoso-Barros 1966) and L. lorenzmuelleri is oviparous (Cortés et al. 1995). Pincheira-Donoso and Núnez (2005) reported that L. maldonadae and $L$. isabelae are viviparous, but the source of this information is unclear (see Lobo et al. 2010:4) since the reproductive mode was not mentioned in the original descriptions (Navarro and Núñez 1993, Núńez et al. 1991).

\section{Discussion}

Almost no molecular data are currently available for the nigroviridis group, probably due to the great difficulties of obtaining samples since all of these species inhabit high altitude mountainous areas (Pincheira-Donoso and Núñez 2005), with only L. constanzae (Ortiz 1975) and L. nigroviridis (Espinoza et al. 2004) recorded below $2000 \mathrm{~m}$ a.s.l. (1400 m a.s.l. and $500 \mathrm{~m}$ a.s.l., respectively). Moreover, most specimens from the MNHNCL and MZUC collections (the two major herpetological collections in Chile) are fixed with formaldehyde, making DNA extraction and amplification challenging (Lin et al. 2009). In 
regards to previous works, Torres-Pérez et al. (2009) performed three phylogenetic analysis (Bayesian inference, ML and maximum parsimony) and found that L. nigroviridis is the basalmost species of a clade also composed of $L$. pseudolemniscatus + L. nigromaculatus + L. platei and that this clade is closely related to L. monticola + L. nitidus clade. Our results are very similar with the nigroviridis and monticola clades as sister groups, but we did not want to include "L. nigromaculatus" from GenBank (Torres-Pérez et al. 2009) because the true identity of this species was only recently clarified (Troncoso-Palacios and Garín 2013) and although a specimen voucher is indicated (CUCH-3143), no locality data is provided. Since we have not seen this specimen we are not sure if it belongs to the true L. nigromaculatus or to L. atacamensis. We also did not include "L. platei" from GenBank (Torres-Pérez et al. 2009) because the specimen voucher (MZUC-30556) was collected in Laja Lagoon, Chile (according to MZUC Book catalog, unpublished) out of the known range for L. platei (Troncoso-Palacios and Marambio-Alfaro 2011), so it could be misidentified. In a recently mitochondrial ML phylogeny performed for a region spanning ND1-COI, Troncoso-Palacios et al. (2015b) found that the L. nigroviridis + L. fuscus clade is the sister group of the monticola clade (L. monticola + L. nitidus + L. confusus). This is also very similar to our result, but since there are not $C y t-b$ data for $L$. fuscus, it could not be included in the present analysis.

We recognize that one limitation to our work is that it is based in a phylogenetic analysis of only one mtDNA gene and that a wider phylogenetic DNA analysis (including nuclear genes) should be conducted in the future. This is also true for most of the 21 species of Liolaemus (sensu stricto) described in the last five years, which have been classified through different methodologies in regards to DNA comparisons. For example, three species (L. chavin, L. pachacutec and L. wari) include data from two mtDNA genes and shared data in GenBank (Aguilar et al. 2013). As our work, five species (L. antumalguen, L. burmeisteri, L. cyaneinotatus, L. lonquimayensis and $L$. ubaghsi) have been described with only $C y t-b$ data, and one species has been described with two mtDNA genes (L. crandalli). However, DNA data from all these have not been shared in GenBank or other online databases (Avila et al. 2010, 2012, 2015, Escobar-Huerta et al. 2015, Esquerré et al. 2014, Martínez et al. 2011) which does not allow the replication of the provided phylogenies or genetic distances. Two described species (Quinteros 2012, Troncoso-Palacios et al. 2015a), L. abdalai and L. zabalai, are supported in regards to DNA features by previously published phylogenetic works. Nine species (L. aparicioi, L. carlosgarini, L. choique, L. chungara, L. nigrocoeruleus, $L$. pyriphlogos, L. riodamas, L. scorialis and L. smaug) have been described without the support of molecular data (Abdala et al. 2010, Esquerré et al. 2013, Marambio-Alfaro and Troncoso-Palacios 2014, Ocampo et al. 2012, Quinteros 2012, Quinteros et al. 2014, Troncoso-Palacios et al. 2015a). Finally, one species, L. shitan, was described (Abdala et al. 2010) despite that no molecular differentiation was previously noted (Morando et al. 2003). No description in the last five year had included nuclear genes or more than two mtDNA genes and in most cases when DNA phylogeny is provided no data are shared in GenBank or other online databases. It is evident that Liolaemus researchers should put emphasis on trying to improve this situation in the future. 
Although L. uniformis is strongly supported as a sister species of L. nigroviridis ( $\mathrm{pp}=$ 1), a comprehensive phylogenetic study with more species of this group is needed. For example, $L$. isabelae was not placed within the nigroviridis group in a mitochondrial phylogenetic study that included one specimen (Schulte and Moreno-Roark 2010), despite that this species has been determined to be a member of this group in cladistic (Lobo 2005) and phenetic studies (Pincheira-Donoso and Núnez 2005) based on morphology. We included this species in our comparisons but for the time being, this should not be considered part of the nigroviridis group. Although the morphological cladistic analysis (Lobo 2005) found five apomorphies for the nigroviridis group (range of scale organs on postrostral scales, fourth supralabial - subocular not in contact, range of lamellae on the fourth finger, intraspecific female pattern and the relationship between the subocular length and the eye diameter), this study does not include all species currently accepted as part of the nigroviridis group and does not indicate the specific variation ranges of variation for these features in this group. On the other hand, the phenetic analysis of Pincheira-Donoso and Núñez (2005) does not provide supporting data for the features that were included in the matrix, so it cannot be replicated (see Lobo et al. 2010).

Liolaemus uniformis resembles L. lorenzmuelleri and L. juanortizi in that the three species share a similar background dorsal coloration. Although no molecular data exists to compare L. uniformis with these two species, we propose that the marked differences in scalation and the strongly allopatric distribution ( $>240 \mathrm{~km}$ of separation), which is quiet considerable for lizards, support classifying L. uniformis as a new taxon. Liolaemus uniformis has probably been misidentified as L. monticola by Núnez et al. (2010), who noted L. monticola as the only lizard species to inhabit in syntopy with Phymaturus alicahuense (no specimen collection indicated). However, the present study found $P$. alicahuense residing at over $2900 \mathrm{~m}$ a.s.l, whereas the upper altitude limit for $L$. monticola is $2000 \mathrm{~m}$ a.s.l. (Espinoza et al. 2004, Fuentes and Ipinza 1979). Therefore, the present data indicates that the only lizards occurring in syntopy with $P$. alicahuense are $L$. uniformis and $L$. nigroviridis. Moreover, L. uniformis and $L$. monticola shows deep morphological and molecular differences. Liolaemus uniformis has probably also been confused with L. bellii (formerly L. altissimus altissimus) by Mella (2005), who found presence of the latter species in the highlands of Putaendo (no specimen collection indicated). However, a field expedition to the highlands of Putaendo by the authors of the present study found no specimens of $L$. bellii, and no additional records of $L$. bellii in this zone are known. Taking into account these details, in addition to both species having a similar background dorsal color, we think that $L$. uniformis might have been confused with $L$. bellii.

Several aspects of the nigroviridis group remain uncertain. For example, L. nigroviridis possibly contains at least two species, the nominal species from the Andean highlands and populations from Coastal highlands, formerly L. n. campanae (Cianferoni et al. 2013). Liolaemus juanortizi might be a junior synonym of L. lorenzmuelleri (Pincheira-Donoso and Núñez 2005), and although both are certainly very similar, it is difficult to carry out a study on this matter because the type series of $L$. juanortizi is lost (Valladares 2011) and there are very few samples of this species (Pincheira-Donoso and Núnez 2005). On the other hand, L. melanopleurus remains a problematic species 
in terms of identification as the type locality is imprecise and no additional specimens have been found in more than 100 years (Troncoso-Palacios 2012).

The present work contributes to the existing taxonomical knowledge, but the $n i$ groviridis group of Liolaemus lizards remains poorly studied, and new samples are required to better investigate its challenging taxonomy.

\section{Acknowledgements}

We thank P. Zabala (Pontificia Universidad de Católica de Chile) for allowing us to review and deposit material in the collection under his care. We are grateful to $\mathrm{H}$. Núñez (Museo Nacional de Historia Natural) and J. Artigas (Museo de Zoología de la Universidad de Concepción) for allowing us to review specimens; K. Kelly (Field Museum of Natural History) for providing photographs of one syntype of Liolaemus melanoplaurus; A. Labra, F. Lobo, R. Díaz and C. Garín for sending literature; and A. VanCott (BioPub Ltda.) for improving the English. H. Díaz for the distribution map. J. Troncoso-Palacios thanks M. Penna and A. Labra for their support. We also thank the three anonymous reviewers that contributed to improving the manuscript. Thanks to the Servicio Agrícola y Ganadero (SAG) for the collecting permit ( $\left.\mathrm{N}^{\circ} 4468\right)$. Red de Observadores de Aves y Fauna de Chile (ROC) for permition to visit the type locality, with special thanks to R. Barros.

\section{References}

Abdala CS, Quinteros AS, Scrocchi GJ, Stazzonelli JC (2010) Three new species of the Liolaemus elongatus group (Iguania: Liolaemidae) from Argentina. Cuadernos de Herpetología 24(2): 93-109.

Aguilar C, Wood Jr PL, Cusi JC, Guzmán A, Huari F, Lundberg M, Mortensen E, Ramirez C, Robles D, Suarez J, Ticona A, Vargas VJ, Venegas PJ, Sites Jr JW (2013) Integrative taxonomy and preliminary assessment of species limits in the Liolaemus walkeri complex (Squamata, Liolaemidae) with descriptions of three new species from Peru. ZooKeys 364: 47-91. doi: 10.3897/zookeys.364.6109

Avila LJ, Morando M, Pérez DR, Sites Jr JW (2010) A new species of the Liolaemus elongatus clade (Reptilia: Iguania: Liolaemini) from Cordillera del Viento, northwestern Patagonia, Neuquén, Argentina. Zootaxa 2667: 28-42.

Avila LJ, Medina CD, Pérez CHF, Sites Jr JW, Morando M (2015) Molecular phylogenetic relationships of the lizard clade Liolaemus elongatus (Iguania: Liolaemini) with the description of a new species from an isolated volcanic peak in northern Patagonia. Zootaxa 3947: 67-84. doi: 10.11646/zootaxa.3947.1.4

Avila LJ, Pérez CHF, Medina CD, Sites Jr JW, Morando M (2012) A new species of lizard of the Liolaemus elongatus clade (Reptilia: Iguania: Liolaemini) from Curi Leuvu River Valley, northern Patagonia, Neuquén, Argentina. Zootaxa 3325: 37-52. 
Cei JM (1993) Reptiles del noroeste, nordeste y este de la Argentina. Herpetofauna de las selvas subtropicales, Puna y Pampas. Museo Regionale di Scienze Naturali di Torino, Monografie 14, 949 pp.

Cianferoni F, Yáñez RP, Palma RE, Garín CF, Torres-Pérez F (2013) Deep divergences within Liolaemus nigroviridis (Squamata, Liolaemidae) lineages associated with Sky Islands in Central Chile. Zootaxa 3619(1): 59-69. doi: 10.11646/zootaxa.3619.1.3

Cortés A, Torres-Mura JC, Contreras L, Pino C (1995) Fauna de vertebrados de los Andes de Coquimbo: Cordillera de Dońa Ana. Ediciones Universidad de La Serena, La Serena, 96 pp.

Coura R (2005) An alternative protocol for DNA extraction from formalin fixed and paraffin wax embedded tissue. Journal of Clinical Pathology 58(8): 894-895. doi: 10.1136/ jcp.2004.021352

Darriba D, Taboada GL, Doallo R, Posada D (2012) jModelTest 2: More models, new heuristics and parallel computing. Nature Methods 9(8): 772. doi: 10.1038/nmeth.2109

Donoso-Barros R (1966) Reptiles de Chile. Ediciones de la Universidad de Chile, Santiago, $458 \mathrm{pp}$.

Edgar RC (2004) MUSCLE: Multiple sequence alignment with high accuracy and high throughput. Nucleic Acids Research 32(5): 1792-1797. doi: 10.1093/nar/gkh340

Escobar-Huerta G, Santibáńez-Toro J, Ortiz JC (2015) Liolaemus lonquimayensis (Squamata: Liolaemidae), a new lizard species for Chile without precloacal pores. Gayana 79(1): 94-101. doi: $10.4067 /$ s0717-65382015000100009

Espinoza RE, Wiens JJ, Tracy CR (2004) Recurrent evolution of herbivory in small, coldclimate lizards: Breaking the ecophysiological rules of reptilian herbivory. Proceedings of the National Academy of Sciences of the United States of America 48: 16819-16824. doi: 10.1073/pnas.0401226101

Esquerré D, Núñez H, Scolaro JA (2013) Liolaemus carlosgarini and Liolaemus riodamas (Squamata: Liolaemidae), two new species of lizards lacking precloacal pores, from Andean areas of Central Chile. Zootaxa 3619(4): 428-452. doi: 10.11646/zootaxa.3619.4.2

Esquerré D, Troncoso-Palacios J, Garín CF, Núñez H (2014) The missing leopard lizard: Liolaemus ubaghsi sp. nov., a new species of the leopardinus clade (Reptilia: Squamata: Liolaemidae) from the Andes of the O'Higgins Region in Chile. Zootaxa 3815(4) 507-525.

Etheridge R (1995) Redescription of Ctenoblepharys adspersa Tschudi, 1845, and the Taxonomy of Liolaeminae (Reptilia: Squamata: Tropiduridae). American Museum Novitates 3142: 1-34.

Fuentes ER, Ipinza J (1979) A note on the diet of Liolaemus monticola (Reptilia, Lacertilia, Iguanidae). Journal of Herpetology 13: 123-124. doi: 10.2307/1563768

Guindon S, Gascuel O (2003) A simple, fast and accurate method to estimate large phylogenies by maximum-likelihood. Systematic Biology 52: 696-704. doi: 10.1080/10635150390235520

Hellmich W (1950) Die eidechsen der ausbeute Schröder (Gattung Liolaemus, Iguan.) (Beiträge zur Kenntnis der Herpetofauna Chiles XIII). Veröffentlichungen Zoologische Staatsammlung München 1: 129-194.

Lin J, Kennedy SH, Svarovsky T, Rogers J, Kemnitz JW, Xu A, Zondervan KT (2009) Highquality genomic DNA extraction from formalin-fixed and paraffin-embedded samples deparaffinized using mineral oil. Analytical Biochemistry 395(2): 265-267. doi: 10.1016/j. ab.2009.08.016 
Lobo F (2001) A phylogenetic analysis of lizards of the Liolaemus chiliensis group (Iguania: Tropiduridae). Herpetological Journal 11: 137-150.

Lobo F (2005) Las relaciones filogenéticas dentro grupo chiliensis (Iguania: Liolaemidae: Liolaemus): sumando nuevos caracteres y taxones. Acta Zoologica Lilloana 49: 65-87.

Lobo F, Espinoza RE, Quinteros AS (2010) A critical review and systematic discussion of recent classification proposals for liolaemid lizards. Zootaxa 2549: 1-30.

Marambio-Alfaro Y, Troncoso-Palacios J (2014) Una nueva especie de Liolaemus del grupo de $L$. nigromaculatus (Iguania: Liolaemidae) para la Región de Atacama, Chile. Basic and Applied Herpetology 28: 65-77.

Martínez LE, Avila LJ, Pérez CHF, Pérez DR, Sites Jr JW, Morando M (2011) A new species of Liolaemus (Squamata, Iguania, Liolaemini) endemic to the Auca Mahuida volcano, northwestern Patagonia, Argentina. Zootaxa 3010: 31-46.

Mella JE (2005) Guía de Campo Reptiles de Chile: Zona Central. Peñaloza APG, Novoa F, Contreras M (Eds) Ediciones del Centro de Ecologia Aplicada Ltda.

Morando M, Avila LJ, Sites Jr JW (2003) Sampling strategies for delimiting species: genes, individuals, and populations in the Liolaemus elongatus-kriegi complex (Squamata: Liolaemidae) in Andean-Patagonian South America. Systematic Biology 52: 159-185. doi: 10.1080/10635150390192717

Navarro J, Núńez H (1993) Liolaemus patriciaturrae y Liolaemus isabelae, dos nuevas especies de lagartijas para el norte de Chile. Aspectos biogeográficos y citotaxonómicos (Squamata, Tropiduridae). Boletín del Museo Nacional de Historia Natural de Chile 44: 99-113.

Núñez H, Jaksic F (1992) Lista comentada de los reptiles terrestres de Chile continental. Boletín del Museo Nacional de Historia Natural de Chile 43: 63-91.

Núñez H, Navarro J, Loyola J (1991) Liolaemus maldonadae y Liolaemus cristiani, dos especies nuevas de lagartijas para Chile (Reptilia, Squamata). Boletín del Museo Nacional de Historia Natural de Chile 42: 79-88.

Núñez H, Veloso A, Espejo P, Veloso C, Cortés A, Araya S (2010) Nuevas especies de Phymaturus (grupo palluma) para la zona Cordillerana Central de Chile (Reptilia, Sauria, Liolaemidae). Boletín del Museo Nacional de Historia Natural de Chile 59: 41-74.

Ocampo M, Aguilar-Kirigin A, Quinteros SA (2012) A new species of Liolaemus (Iguania: Liolaemidae) of the alticolor group from La Paz, Bolivia. Herpetologica 68(3): 410-417. doi: 10.1655/HERPETOLOGICA-D-12-00001.1

Ortiz JC (1975) Una nueva especie de lagartija chilena, Liolaemus donosoi sp. nov. (SquamataIguanidae). Anales del Museo de Historia Natural de Valparaíso 8: 62-65.

Philippi RA (1860) Reise durch die wüste Atacama, auf befehl der chilenischen regierung im sommer 1853-1854. Halle, Eduard Anton, 192 pp.

Pincheira-Donoso D, Núñez H (2005) Las especies chilenas del género Liolaemus (Iguanidae Tropiduridae, Liolaeminae). Taxonomía, sistemática y evolución. Publicación Ocasional del Museo Nacional de Historia Natural de Chile 59: 7-486.

Pincheira-Donoso D, Núñez H (2007) Conspecificity of Liolaemus isabelae Navarro \& Núñez, 1993 and Liolaemus nigroventrolateralis Ortiz, 1994 (Iguania: Tropiduridae: Liolaeminae) from Northern Chile. Herpetological Journal 17: 65-67. 
Quinteros SA (2012) Taxonomy of the Liolaemus alticolor-bibronii Group (Iguania: Liolaemidae), with descriptions of two new species. Herpetologica 68(1): 100-120. doi: 10.1655/ HERPETOLOGICA-D-10-00065.1

Quinteros SA, Valladares P, Semham R, Acosta JL, Barrionuevo S, Abdala CS (2014) A new species of Liolaemus (Iguania: Liolaemidae) of the alticolor-bibronii group from northern Chile. South American Journal of Herpetology 9(1): 20-29. doi: 10.2994/SAJHD-13-00040.1

Ronquist F, Huelsenbeck JP (2003) MRBAYES 3: Bayesian phylogenetic inference under mixed models. Bioinformatics 19: 1572-1574. doi: 10.1093/bioinformatics/btg180

Schulte JA, Moreno-Roark F (2010) Live birth among Iguanian lizards predates Pliocene-Pleistocene glaciations. Biology Letters 6: 216-218. doi: 10.1098/rsbl.2009.0707

Torres-Pérez F, Mendez MA, Benavides E, Moreno RA, Lamborot M, Palma RE, Ortiz JC (2009) Systematics and evolutionary relationships of the mountain lizard Liolaemus monticola (Liolaemini): how morphological and molecular evidence contributes to reveal hidden species diversity. Biological Journal of the Linnean Society 96: 635-650. doi: 10.1111/j.1095-8312.2008.01140.x

Troncoso-Palacios J (2012) Comentarios sobre el enigmático Liolaemus melanopleurus (Philippi 1860) a 152 años de su descripción. La Chiricoca 14: 14-21.

Troncoso-Palacios J (2013) Revisión del estatus taxonómico de Liolaemus donosoi Ortiz, 1975 (Iguania: Liolaemidae). Boletín del Museo Nacional de Historia Natural de Chile 62: 119-127.

Troncoso-Palacios J, Garín CF (2013) On the identity of Liolaemus nigromaculatus Wiegmann, 1834 (Iguania, Liolaemidae) and correction of its type locality. ZooKeys 294: 37-56.

Troncoso-Palacios J, Marambio-Alfaro Y (2011) Lista comentada de los reptiles de la Región de Atacama. Boletín del Museo Regional de Atacama 2: 60-78.

Troncoso-Palacios J, Díaz HA, Esquerré D, Urra FA (2015a) Two new species of the Liolaemus elongatus-kriegi complex (Iguania, Liolaemidae) from Andean highlands of southern Chile. ZooKeys 500: 83-109. doi: 10.3897/zookeys.500.8725

Troncoso-Palacios J, Schulte II JA, Marambio-Alfaro Y, Hiriart D (2015b) Phenotypic variation, phylogenetic position and new distributional records for the poorly known Liolaemus silvai Ortiz, 1989 (Iguania: Iguanidae: Liolaemini). South American Journal of Herpetology 10(2): 71-81.

Valencia J, Veloso A, Sallaberry M (1979) Biometric and chromosomic analysis of populations of Liolaemus nigroviridis Muller and Hellmich (Squamata-Iguanidae). Archivos de Biología y Medicina Experimentales 12: 209-220.

Valladares P (2011) Análisis, síntesis y evaluación de la literatura de lagartos de la Región de Atacama, Chile. Gayana 75: 81-98. doi: 10.4067/S0717-65382011000100006

Veloso A, Sallaberry M, Navarro J, Iturra P, Valencia J, Penna M, Díaz N (1982) Contribución sistemática al conocimiento de la herpetofauna del extremo norte de Chile. In: Veloso A, Bustos E (Eds) El hombre y los ecosistemas de montańa. Oficina Regional de Ciencias y Tecnología de la UNESCO para América Latina y el Caribe, Montevideo, I, 135-268. 


\section{Appendix I}

Specimens examined. Acronyms are: Field Museum of Natural History (FMNH), Museo Nacional de Historia Natural de Chile (MNHNCL), Museo de Zoología de la Universidad de Concepción (MZUC) and Colección de Flora y Fauna, Profesor Patricio Sánchez Reyes de la Pontificia Universidad Católica de Chile (SSUC).

Liolaemus bellii. MNHNCL 1599. Sewell, O`Higgins Region, Chile. Elgueta M. coll. December 1982. SSUC 201-05. Casa de Piedra, Farellones, Metropolitan Region, Chile. Ferri F. coll. 12/10/2010. SSUC Re 206-09. El Colorado, Farellones, Metropolitan Region, Chile. Ferri F. coll. 13/11/2011. SSUC Re 398-404, 543. El Olivares, Metropolitan Region, Chile. Garín C. coll. SSUC Re 562-66. La Parva, Metropolitan Region, Chile. Opazo J. coll. December, 2003. SSUC Re 654, 656. Lagunillas, Metropolitan Region, Chile. Esquerré D. 15/02/2015.

Liolaemus constanzae. MZUC 29247, 29250-51. Toconao, Antofagasta Region. Unknown collector and date. MZUC 28763-65, 28767-69. Agua Verde (Quebrada de Taltal), Antofagasta Region. J.C. Ortiz, S. Zunino \& M. Riveros colls. 10/02/1975. SSUC Re 338-347. Cuesta Barros Arana, Antofagasta Region. Ferri F. coll. 22/10/2011. SSUC Re 348. Southern Salar de Atacama, Antofagasta Region. Ferri F. coll. 24/10/2011. SSUC RE 482-83, 485, 488. El Abra, Antofagasta Region. G. Lobos \& F. Torres colls. 22/11/2003. MNHNCL 1499-1500. Quebrada de Taltal, Agua Verde, 1400 m, Antofagasta Region. S. Zunino \& M. Riveros colls. 10/02/1975. MNHNCL 1516-1520. Quebrada de Taltal, Agua Verde, 1480 m, Antofagasta Region. 27/09/1982. Núñez, Yáñez \& Contreras colls.

Liolaemus isabelae. SSUC Re 157, 159, 160. El Cerrito, Salar de Pedernales, Atacama Region. F. Ferri \& J. Troncoso-Palacios colls. 22/02/2012. SSUC Re 158. Montandón, Salar de Pedernales, Atacama Region. F. Ferri \& J. Troncoso-Palacios colls. 22/02/2012.

Liolaemus juanortizi. MZUC 11782. Río Patón, Atacama Region. Cekalovic T. coll. 20/12/1963.

Liolaemus lorenzmuelleri. MNHNCL 2401, 2403, 2404, 2406-08. El Indio, Baños del

Toro, Coquimbo Region. H. Núñez \& J.C. Torres-Mura colls. 18-22/12/1992. MNHNCL 1708. La Laguna, Valle del Elqui, 3300 m, Coquimbo Region. L. Contreras coll. December, 1982. MZUC 37863-64. Valle de Los Helados, Copiapó, Atacama Region. Asociación de Andinistas de Atacama colls. 13/04/1984.

Liolaemus maldonadae. SSUC Re 304, 305, 560. Quebrada Los Piuquenes, Interior de Alcohuaz, Paihuano, Río Claro, Coquimbo Region. Troncoso-Palacios, J., F. Lobo, A. Laspiur \& J.C. Acosta Colls. 10/02/2011.

Liolaemus melanopleurus. MNHNCL 1646 (2 specimens). Atacama. R.A. Philippi col. FMNH 9969 (only digital photographs). Atacama. R.A. Philippi coll.

Liolaemus monticola. SSUC Re 372-79. Camino a Farellones, Curva 20, Metropolitan Region, Chile. Ferri F. coll. 15/03/2012. 
Liolaemus nigroviridis. MNHNCL 214-215. San Ramón, 3000 m, Metropolitan Region. H. Núńez coll. February, 1979. SSUC Re 016. El Yeso, Metropolitan Region. C. Garín coll. 01/04/2004. SSUC Re 190-200. Farellones, Casa de Piedra, Camino a Valle Nevado, Metropolitan Region. F. Ferri coll. 12/10/2010.

Liolaemus uniformis. SSUC Re 674-79. West shore of the Chepical Lagoon, approximately $30 \mathrm{~km}$ NE Alicahue, San Felipe de Aconcagua Province, Valparaíso Region, Chile. J. Troncoso-Palacios \& E. Alfaro. December, 2012.

\section{Appendix II}

Specimens used for phylogenetic analysis.

mtDNA sequences obtained in this study. Liolaemus uniformis sp. n.: SSUC Re 674, KU095836. SSUC Re 677 KU095837. L. nitidus: SSUC Re 298, Dunas de Ritoqui, Valparaíso Region, Chile. KU095835. L. confusus: SSUC Re 356, Cerro Robles Riscos de Jote, O'Higgins Region, Chile. KU095832. L. curicensis: SSUC Re 253, Termas del Flaco, O'Higgins, Chile. KU095833. L. kuhlmanni: SSUC Re 285, Termas del Flaco, O`Higgins, Chile. KU095834. L. bellii: SSUC Re 208, El Colorado, Farellones, Metropolitan Region. KU095830. L. bellii: SSUC Re 209, El Colorado, Farellones, Metropolitan Region. KU095831.

mtDNA sequences obtained from GenBank. Liolaemus nigroviridis: Farellones. KC313199, KC313202, KC313203, KC313204, KC313205, KC313206, KC313208, KC313211, KC313207, KC313210, KC313209. L. monticola: Yerba Loca AY850619, Alfalfal AY850616, Maipú AY851724, Cuesta Chacabuco AY851718, Quebrada Alvarado AY851726, Colorado Norte AY851713, Cabrería AY851708, Rocín AY851710. L. tenuis: Termas de Chillán DQ989790. L. abdalai: Valle Chimehuin JN410525. L. alticolor: Huancarani KF923660. Santa Ana KF923659. L. austromendocinus: Nihuil AY173838. L. buergeri: El Planchón KJ494079, KJ494070, KJ494080. L. capillitas: Ruta Provincial AY173844. L. chiliensis: Termas de Chillan DQ989785, Las Trancas EU649245. L. cyanogaster: Tucapel DQ989786. L. dicktracy: Alto del Carrizal AY367816. L. elongatus: Esquel AY173801, Gobernador Costa AY173818, Los Manantiales AY173826, Laguna Blanca AY173855, Pampa de Lonco Luan AY173827, Las Ardillas AY173852. L. gununakuna: La Amarga AY367807, AY173859. L. incaicus: Urco KF923658, Lucre KF923657. L. kriegi: all from Río Negro Province AY173802, KJ494012, KJ494150, KJ494190, AY173814, KJ494155, KJ494191, KJ494188. L. neuquensis: Primeros Pinos AY173828. L. parvus: Quebrada Honda AY173836. L. petrophilus: El Cuy AY173796, Los Menucos JN847211, Ingeniero Jacobacci JN847103. L. pictus: San Carlos de Bariloche AY173795. L. punmahuida: Volcán Tromen AY173824. L. ramirezae: E Amaicha del Valle JN410520. L. robertmertensi: Tinogasta DQ989769. L. saxatilis: Achiras JN410553, Río Cuarto 
JN410527. L. smaug: Las Leñas AY173832, Mallines Colgados AY173830. L. talampaya: Las Yeguas River AY173797. L. tregenzai: all from Termas de Copahue AY367817, KJ494036, KJ494230, KJ494040, KJ494039, KJ494037, KJ494038. L. tulkas: Quebrada Las Angosturas AY367813. L. umbrifer: Quebrada de Randolfo AY367814. L. villaricensis: Volcán Villarrica AY850629, AY730671. L. zabalai: all from Biobío Region KJ494059, KJ494056, KJ494057, KJ494086, KJ494074, KJ494085. Phymaturus vociferator: Laguna del Laja JX969016. Phymaturus felixi: Paso de Indios JX969044. 